Volume 10, Nomor 2, November 2018, pp 139-148 Copyright (C) 2017 Jurnal Akuntansi Maranatha, Program Studi Akuntansi, Fakultas Ekonomi,

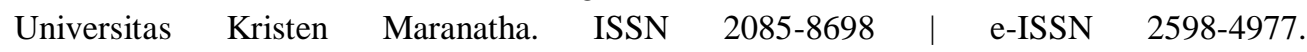
http://journal.maranatha.edu

\title{
Implementasi Sistem Informasi dan Strategi pada Industri Travel di Kota Yogyakarta
}

\author{
Fauzy Besta Pratamayuda \\ Program Studi Akuntansi Fakultas Ekonomi \\ Universitas Islam Indonesia \\ fauzy.besta@gmail.com \\ Fitriati Akmila \\ Program Studi Akuntansi Fakultas Ekonomi \\ Universitas Islam Indonesia \\ fitriati@uii.ac.id
}

\begin{abstract}
Information System are series of activities that process data becoming information. Strategy are plans made to achieve goals. The purpose if this research is to investigate the implementation of information system with information technology, management information system, accounting information system and the strategies implemented by the travel industries in the city of Yogyakarta in facing online travel agents. This research is a qualitative descriptive research with interview and observation for data collection. The results of this research shows that travel industries already use information system and strategies well. For the business process in each travel industries, they already use information system although the system is not yet integrated. Moreover, selling strategies they took has influenced their sales though they did not reached their profit target.
\end{abstract}

Keywords: Travel Industries, Information Technology, Information Systems, Strategies

\section{Pendahuluan}

Sektor pariwisata merupakan salah satu aset berharga yang dimiliki Indonesia yang mampu mendorong pertumbuhan perekonomian negara. Berdasarkan Laporan Kinerja KemenPar RI di tahun 2016, PDB yang dihasilkan dari sektor pariwisata mencapai 500,19 triliun rupiah. Dalam rangka mengembangkan sektor pariwisata, Indonesia terus melakukan upaya perbaikan dan peningkatan di sektor tersebut dengan menjadikan pariwisata sebagai program prioritas nasional dalam Rencana Pembangunan Jangka Menengah (RPJM) tahun 2015-2019 (Khumaedy, 2017). 
Yogyakarta menjadi salah satu daerah yang terus berupaya melakukan pengembangan sektor pariwisata karena sektor tersebut mampu menyumbangkan Pendapatan Asli Daerah (PAD) sebanyak 353 miliar rupiah yang didominasi oleh PAD dari sub sektor pariwisata di wilayah Kotamadya/Kota Yogyakarta sebesar 162 miliar rupiah (Kristianto et al., 2016). Menurut Kepala Dinas Pariwisata DIY Aris Riyanta, wisatawan yang menyumbang APBD terbesar melalui sektor pariwisata justru wisatawan domestik yang berasal dari luar Kota Yogyakarta (tribunjogja.com, 17 Oktober 2016).

Berkembangnya sektor pariwisata di Yogyakarta berdampak pula pada berkembangnya industri jasa perjalanan atau industri travel yang ingin menangkap peluang bisnis tersebut. Badan Pusat Statistik (BPS) DIY mencatat jumlah industri travel pada tahun 2016 total mencapai 173 biro/agen perjalanan wisata khusus di wilayah Kotamadya/Kota Yogyakarta (Kristianto et al., 2016). Banyaknya industri travel semakin meningkatkan persaingan usaha di sektor tersebut. Terlebih lagi sejak lima tahun terakhir, trend pembelian tiket perjalanan secara online semakin meningkat (keretaapi.info, 14 Oktober 2016). Agen travel online/Online Travel Agent (OTA) merupakan tantangan nyata bagi industri travel yang bergerak secara tradisional. Industri travel tradisional merupakan istilah bagi agen travel yang menyediakan jasa perjalanan dan menjual tiket secara langsung kepada konsumen melalui gerai/toko.

Wakil Ketua Asosiasi Perhimpunan Hotel dan Restoran Indonesia (PHRI) Sudrajat mengemukakan agen travel yang masih bergerak secara tradisional semakin lama semakin redup karena terjadi penurunan penjualan, hal tersebut disebabkan sebanyak $60 \%$ publik sudah mulai pindah ke pembelian secara online (detik.com, 14 Agustus 2017). Untuk menghadapi persaingan tersebut, industri travel tradisional harus menyiapkan strategi agar perusahaan dapat terus hidup dan bertahan. Selain itu, hal yang penting dilakukan adalah memaksimalkan penerapan sistem informasi di dalam perusahaan. Sistem informasi memberikan informasi yang berguna bagi perusahaan, sehingga semakin bagus penerapan sistem, maka semakin tepat dan akurat informasi yang dihasilkan bagi pengambil keputusan. Hal tersebut dapat meningkatkan daya saing perusahaan.

Penelitian ini dilakukan untuk mengetahui implementasi sistem informasi pada industri travel di Kota Yogyakarta serta strategi apa yang digunakan dalam menghadapi persaingan dengan OTA, sehingga dirumuskan permasalahan sebagai berikut: (1) Bagaimana penerapan sistem informasi pada industri travel di Kota Yogyakarta? (2) Bagaimana strategi yang dilakukan oleh industri travel di Kota Yogayakarta dalam menghadapi persaingan dengan OTA?

\section{Kerangka Teoritis dan Hipotesis}

\section{Industri Travel}

Industri travel merupakan bagian dari pariwisata dimana sektor usaha tersebut bergerak di bidang pelayanan dan penyediaan barang dan atau jasa perjalanan bagi para wisatawan melalui agen tour dan travel. Definisi agen travel dimuat dalam Undang-Undang Republik Indonesia Nomor 10 Tahun 2009 tentang Kepariwisataan dimana dijelaskan bahwa usaha pariwisata adalah usaha yang menyediakan barang dan/atau jasa bagi pemenuhan kebutuhan wisatawan dan penyelenggaraan pariwisata.

Di Indonesia terdapat organisasi resmi yang menjadi wadah bagi industri travel atau asosiasi agen travel, yaitu ASITA (Association of the Indonesian Tours and Travel Agencies) dan ASTINDO (Asosiasi TravelAgent Indonesia). Berdasarkan website resmi dari organisasi tersebut, 
ASITA adalah suatu perkumpulan yang mewadahi pengusaha atau pelaku usaha di bidang jasa perjalanan wisata di Indonesia. Organisasi lainnya yaitu ASTINDO sendiri merupakan asosiasi dari berbagai agen travel yang mengutamakan bisnis ticketing dari berbagai airlines. ASTINDO bernaung di bawah Direktorat Jenderal Perhubungan Udara, yang disahkan melalui Surat Keputusan (SK) Menteri Perhubungan Republik Indonesia dengan No. KP 263 tahun 2000. Tujuan didirikannya ASTINDO adalah untuk memajukan, dan melindungi kepentingan agen travel khususnya dalam penjualan tiket penerbangan dan sekaligus untuk mencari solusi dalam menyelesaikan permasalahan tata niaga bisnis anggota.

\section{Teknologi Informasi}

Teknologi informasi (TI) menurut Urumsah (2014) merupakan sarana untuk memfasilitasi, mengakuisisi, memproses, menyimpan, menyampaikan, dan membagi informasi karena TI secara spesifik mengacu pada teknologi perangkat keras (hardware), perangkat lunak (software), dan jaringan telekomunikasi (networking telecommunication). Laudon dan Laudon (2014) mendefinisikan teknologi informasi sebagai salah satu dari banyak perangkat yang digunakan manajer dalam mengantisipasi perubahan. Seluruh teknologi tersebut beserta orang-orang yang menjalankan dan mengelola, serta sumber daya lain dari organisasi membentuk suatu rangkaian yang disebut infrastruktur teknologi informasi. Infrastruktur TI menyediakan dasar dimana perusahaan dapat membangun sistem informasi yang terspesifikasi.

\section{Sistem Informasi Manajemen}

Sistem Informasi Manajemen (SIM) adalah sebuah kesatuan, sistem mesin pengguna yang terintegrasi dalam memberikan informasi untuk mendukung operasi, manajemen, dan fungsi pembuatan keputusan dalam suatu organisasi. Sistem yang dimaksud adalah sistem yang menggunakan perangkat keras dan perangkat lunak komputer, prosedur manual, model yang digunakan untuk menganalisis, merencanakan, mengendalikan, dan membuat keputusan serta sebuah basis data (Gaol, 2008).

SIM digunakan untuk meningkatkan efektivitas manajemen, dengan memuaskan berbagai kebutuhan informasi untuk pengambilan keputusan (Urumsah, 2014). Adanya SIM terintegrasi membuat proses bisnis yang dijalankan menjadi lebih efektif dan efisien karena semua proses bisnis dapat dijalankan menggunakan satu sistem terintegrasi tersebut. Selain itu semua data yang disimpan di dalam sistem juga dapat dengan mudah diambil dan ditampilkan di dalam sistem tersebut, sehingga semua data yang dibutuhkan dapat dengan mudah digunakan oleh pengambil keputusan.

\section{Sistem Informasi Akuntansi}

Sistem Informasi Akuntansi (SIA) menurut Romney dan Steinbart (2015) adalah suatu alat penyedia informasi akuntansi, dimana sistem tersebut mengumpulkan, mencatat, menyimpan, serta mengolah/melakukan proses akuntansidan data lain untuk menghasilkan informasi bagi pembuat keputusan. Sistem informasi akuntansi memiliki enam komponen, yaitu orang yang menggunakan sistem, prosedur dan instruksi yang digunakan untuk mengumpulkan, mengolah, dan menyimpan data, data mengenai organisasi dan aktivitas bisnis, software yang digunakan untuk mengolah data, infrastruktur teknologi informasi, termasuk komputer, perangkat pendukung, dan jaringan internet yang digunakan di dalam sistem informasi akuntansi, dan pengendalian internal dan keamanan yang dapat mengamankan data.

SIA sangat bermanfaat karena dapat menambah nilai bagi organisasi. Fungsifungsi sistem informasi akuntansi sendiri bagi organisasi menurut Romney dan Steinbart (2015) yaitu meningkatkan kualitas dan mengurangi biaya dari 
barang/jasa, meningkatkan efisiensi, berbagi pengetahuan, meningkatkan efisiensi dan efektivitas rantai pasokannya, meningkatkan struktur pengendalian internal, meningkatkan pengambilan keputusan.

\section{Strategi}

Strategi menurut Govindarajan dan Anthony (2007) adalah rencana-rencana yang digunakan untuk mencapai tujuan organisasi. Strategi dapat ditemukan pada dua tingkatan, yaitu strategi tingkat korporat (corporatelevel) dan strategi tingkat unit bisnis (businessunitlevel). Strategi korporat adalah mengenai keberadaan di tengah-tengah bauran bisnis yang tepat sehingga strategi ini lebih berkenaan dengan pertanyaan dimana sebaiknya bersaing, sedangkan strategi unit bisnis adalah mengenai bagaimana bersaing dalam industri tertentu.

Berikut ini adalah macam-macam strategi menurut Govindarajan dan Anthony (2007) berdasar masing-masing tingkatan, yaitu:

1. Strategi Tingkat Korporat

a. Industri Tunggal, yaitu strategi perusahaan dengan fokus hanya pada satu industri.

b. Diversifikasi Berhubungan, yaitu strategi perusahaan dengan beroperasi dalam sejumlah industri yang sama dan bisnisnya saling berhubungan satu sama lain melalui sinergi operasi.

c. Diversifikasi Tidak Berhubungan, yaitu strategi perusahaan dengan beroperasi dalam sejumlah industri yang berbeda.

2. Strategi Tingkat Unis Bisnis

a. Bangun, yaitu strategi dengan tujuan menambah pangsa pasar, bahkan dengan mengorbankan laba jangka pendek dan arus kas.

b. Pertahankan, yaitu strategi dengan melindungi pangsa pasar yang sudah dikuasai serta mempertahankan posisi persaingan.

c. Panen, yaitu strategi dengan tujuan memaksimalkan laba jangka pendek dan arus kas, bahkan dengan mengorbankan pangsa pasar.

d. Divestasi/jual, yaitu strategi dengan menunjukkan suatu keputusan untuk mundur dari bisnis melalui proses likuidasi perlahan-lahan atau penjualan segera.

e. Biaya Rendah, yaitu strategi dengan upaya meminimalkan/menekan biaya serendah mungkin.

f. Diferensiasi, yaitu strategi dengan menciptakan keunikan tersendiri dalam pasar yang menjadi sasarannya.

Teori Konfirmasi Harapan (Expectation Confirmation Theory)

Teori konfirmasi harapan (ECT) merupakan teori yang dikembangkan oleh Oliver (1980) tentang kepuasan. Oliver (1980) mengemukakan bahwa harapan ditambah dengan kinerja akan menghasilkan kepuasan. Teori konfirmasi harapan menekankan kepada penilaian pasca niat pembelian yang dipengaruhi oleh harapan awal tentang suatu produk atau jasa, adopsi, dan niat keberlanjutan penggunaan.

Teori konfirmasi harapan memiliki empat aspek, yaitu ekspektasi, kinerja yang dirasakan, diskonfirmasi, dan kepuasan. Tingkat kepuasan tersebut diperoleh dari diskonfirmasi dan harapan terhadap layanan pada suatu poduk atau sistem. Diskonfirmasi tersebut dapat berupa diskonfirmasi positif dan diskonfirmasi negatif. Diskonfirmasi positif (positifdisconfirmation) terjadi ketika kinerja aktual dapat memenuhi atau mencapai target dari standar yang diharapkan, sedangkan diskonfirmasi negatif (negativedisconfirmation) terjadi ketika kinerja aktual gagal dalam memenuhi 
atau mencapai target dari standar yang diharapkan.

\section{Penelitian Terdahulu}

Penelitian mengenai penggunaan TI sudah pernah dilakukan oleh Wahid dan Iswari (2007). Penelitian tersebut menyatakan bahwa penggunaan TI pada industri kecil menengah masih rendah dikarenakan banyak faktor yang menghambat adopsi TI seperti belum munculnya kebutuhan terhadap TI dalam mendukung proses bisnis dan kurangnya dukungan finansial. Pengguna TI masih pada tataran operasional atau oportunistik, dan belum sampai pada tingkatan strategis. Dalam penelitian yang dilakukan Ceisari (2017), disimpulkan bahwa penerapan sistem informasi sudah dilakukan oleh sebagian usaha kecil menengah meskipun dalam praktiknya belum maksimal.

Penelitian mengenai penerapan sistem informasi akuntansi sudah pernah dilakukan oleh Musmini (2013). Dalam penelitian tersebut menyebutkan bahwa sistem informasi akuntansi yang dimiliki usaha kecil masih sangat sederhana dan tidak sistemastis, dalam artian tidak memadai, sehingga tidak dapat memberikan informasi bagi manajer untuk mengambil keputusan. Manajer tidak dapat melihat dengan baik perkembangan dan kinerja usahanya dengan baik dari informasi ataupun catatan yang dimiliki. Selanjutnya Adron (2016) menyatakan bahwa kegiatan akuntansi pada usaha kecil menengah masih sangat rendah dan hanya sebagian kecil dari mereka yang membuat laporan keuangan. Selain itu dalam penelitian mengenai penggunaan strategi pada agen travel sudah pernah dilakukan oleh Anjastantri dan Dewantara (2017). Dalam penelitian tersebut menemukan bahwa agen travel yang menjadi objek penelitian tersebut menggunakan strategi pengembangan pasar dengan melakukan penjualan produk barang dan jasa di wilayah pemasaran yang baru.

\section{Metode Penelitian}

\section{Jenis Penelitian}

Menurut Moleong (2014) penelitian kualitatif adalah penelitian yang bermaksud untuk memahami fenomena tentang apa yang dialami oleh subjek penelitian misalnya perilaku, persepsi, motivasi, tindakan, dll., secara holistik, dan dengan cara deskripsi dalam bentuk kata-kata dan bahasa, pada suatu konteks khusus yang alamiah dan dengan memanfaatkan berbagai metode alamiah. Peneliti menggunakan metode kualitatif karena dalam penelitian ini dibutuhkan data yang mendalam guna melakukan analisis sehingga didapat hasil yang sesuai dengan kondisi sebenarnya

\section{Populasi dan Sampel}

Dalam penelitian ini, peneliti menggunakan teknik sampling non-probability dengan jenis purposive sampling. Purposive sampling merupakan teknik pemilihan sampel yang akan dijadikan sebagai responden/informan dalam penelitian berdasarkan pada kesesuaian ciri-ciri atau karakteristik yang dimiliki oleh subyek dengan tujuan dari topik penelitian. Dalam penelitian ini, peneliti menentukan kriteria terlebih dahulu dalam pemilihan sampel. Sampel yang peneliti pilih dalam penelitian ini adalah agen tour dan travel khusus untuk wilayah Kotamadya/Kota Yogyakarta yang aktif tergabung dalam ASITA. Hal tersebut peneliti pilih karena agen tour dan travel yang tergabung dalam ASITA merupakan agen-agen yang memiliki bisnis/usaha yang jelas dengan kredibilitas baik mengingat untuk bergabung menjadi anggota ASITA terdapat sejumlah persyaratan yang harus dipenuhi.

\section{Metode Pengumpulan Data}

Penelitian ini menggunakan sumber data dari wawancara dan literatur. Sumber data wawancara didapatkan dari wawancara kepada informan yaitu manajer dari agen tour dan travel di Kota Yogyakarta. Dalam 
penelitian ini, peneliti berhasil melakukan wawancara kepada 4 orang manajer dari masing-masing agen tour dan travel. Data yang dijadikan sebagai sumber penelitian yaitu data hasil wawancara terkait penggunaan sistem informasi berupa penggunaan teknologi informasi, penerapan sistem informasi akuntansi, serta strategi yang digunakan untuk menghadapi persaingan dengan agen travel online. Selain itu terdapat sumber data literatur yang digunakan oleh peneliti berasal dari berbagai macam literatur yang dianggap relevan dengan topik penelitian.

\section{Metode Analisis Data}

Dalam penelitian ini, thematic analysis digunakan sebagai alat untuk menganalisis data. Boyatzis(1980)menyatakan bahwa thematic analysis merupakan cara mengidentifikasi tema-tema yang terpola dalam suatu fenomena. Tema-tema tersebut dapat diidentifikasi, dikodekan secara induktif (data driven) dari data kualitatif mentah (transkrip wawancara, biografi, rekaman video, dan sebagainya) maupun secara deduktif (theory driven) berdasarkan teori maupun hasil penelitian terdahulu. Penelitian ini diidentifikasi secara induktif karena data yang dimiliki merupakan data mentah yang diperolah melalui wawancara. Dalam melakukan analisa, terdapat langkah-langkah yang harus dilakukan.

Sekaran dan Bougie (2017) menyebutkan tiga langkah dalam analisis data kualitatif yaitu reduksi data, penyajian data, dan penarikan kesimpulan. Reduksi data mengacu pada proses memilih, mengodekan, dan mengategorikan data. Penyajian data merujuk pada cara menunjukkan atau menyajikan data, yaitu dengan cara terorganisasi dan singkat. Langkah yang terakhir adalah penarikan kesimpulan, yaitu menjawab pertanyaan penelitian dengan menentukan apa yang diwakili oleh tema yang teridentifikasi dengan mempertimbangkan penjelasan untuk pola dan hubungan yang diteliti atau dengan membuat kontras dan perbandingan.
Langkah-langkah yang dilakukan untuk menganalisa data dalam penelitian ini, pertama data dikategorikan menjadi empat, yaitu penggunaan Teknologi Informasi (TI), penerapan Sistem Informasi Manajemen (SIM), penerapan Sistem Informasi Akuntansi (SIA), dan strategi yang digunakan. Setelah data dikategorikan, data tersebut disajikan ke dalam bentuk tabel dengan menggunakan tabulasi Spread sheet. Langkah terakhir yaitu penarikan kesimpulan berdasarkan data yang telah tersaji dalam bentuk tabulasi tersebut guna menjawab pertanyaan rumusan masalah dalam topik penelitian ini.

\section{Hasil Penelitian dan Pembahasan}

\section{Hasil Pengumpulan Data}

Dalam penelitian ini, peneliti berhasil mengumpulkan data melalui wawancara dengan 4 responden agen tour dan travel yang berada di Kota Yogyakarta. Tabel 1. menguraikan deskripsi 4 responden sebagai sumber informasi dalam penelitian ini.

\section{Tabel 1}

\section{Daftar Responden Agen Travel di Kota Yogyakarta}

\begin{tabular}{|l|l|l|l|l|}
\hline No & Nama & Alamat & $\begin{array}{l}\text { Jumlah } \\
\text { Cabang }\end{array}$ & Omset \\
\hline 1 & KWTT & $\begin{array}{l}\text { Jl. Margo Utomo } \\
\text { No.40-46, } \\
\text { Gowongan, Jetis, } \\
\text { Kota Yogyakarta, } \\
\text { Daerah Istimewa } \\
\text { Yogyakarta } \\
\text { 55232 }\end{array}$ & $\begin{array}{l} \pm 2 \\
\text { miliar }\end{array}$ \\
\hline 2 & MTT & $\begin{array}{l}\text { J1. MT. Haryono } \\
\text { No.79, } \\
\text { Suryodiningratan, } \\
\text { Mantrijeron, } \\
\text { Kota Yogyakarta, } \\
\text { Daerah Istimewa } \\
\text { Yogyakarta } \\
55141 \text { miliar }\end{array}$ & 2 & \\
\hline
\end{tabular}




\begin{tabular}{|c|c|c|c|c|}
\hline 3 & SRTT & $\begin{array}{l}\text { Jl. Kusumanegara } \\
\text { No.218, Muja } \\
\text { Muju, } \\
\text { Umbulharjo, } \\
\text { Kota Yogyakarta, } \\
\text { Daerah Istimewa } \\
\text { Yogyakarta } \\
\text { 55165 }\end{array}$ & 1 & $\begin{array}{l} \pm 800 \\
\text { juta }\end{array}$ \\
\hline 4 & TTT & $\begin{array}{l}\text { Jl. Kusumanegara } \\
\text { No.114, Muja } \\
\text { Muju, } \\
\text { Umbulharjo, } \\
\text { Kota Yogyakarta, } \\
\text { Daerah Istimewa } \\
\text { Yogyakarta } \\
55165\end{array}$ & 1 & $\begin{array}{l}1,5-2 \\
\text { miliar }\end{array}$ \\
\hline
\end{tabular}

\section{Analisis Data}

\section{Penerapan Teknologi Informasi pada Industri Travel}

Berdasarkan hasil wawancara yang dilakukan, semua agen tour dan travel yang menjadi responden dalam penelitian ini sudah menggunakan TI dalam menjalankan usahanya karena memang dalam industri travel ini dibutuhkan TI dalam proses bisnisnya. Semua responden sudah menggunakan TI terutama dalam pemesanan tiket kepada supplier. Pemanfaatan TI untuk keperluan sistem informasi di perusahaan juga sudah cukup maksimal digunakan. Semua responden dalam penelitian ini sudah menggunakan TI sebagai alat pengolah data keuangan yang dapat menghasilkan informasi akuntansi bagi perusahaan. Mereka menggunakan TI untuk mencatat semua transaksi dan membuat laporan keuangan perusahaan. Selain itu, semua data perusahaan seperti data supplier dan data konsumen sudah disimpan secara digital di dalam komputer. Semua agen tour dan travel juga sudah memanfaatkan TI sebagai alat pemasaran, dimana mereka melakukan promosi dengan memasang iklan secara digital melalui website maupun media sosial.

\section{Implementasi Sistem Informasi}

Semua agen tour dan travel yang menjadi responden dalam penelitian ini sudah menerapkan sistem informasi manajemen (SIM) dengan cukup baik. Mereka sudah menggunakan sistem untuk memasukkan data untuk kemudian diolah menjadi informasi yang berguna bagi pengambil keputusan. Namun, sistem informasi manajemen yang digunakan oleh ke semua agen tour dan travel tersebut belum ada yang memiliki sistem terintegrasi. Sistem yang mereka gunakan merupakan sistem yang masih terpisah-pisah seperti data keuangan diolah menggunakan sistem akuntansi sendiri, data supplier dan pelanggan diolah menggunakan sistem sendiri, serta pemesanan tiket juga dilakukan dengan menggunakan sistem tersendiri sehingga data tidak secara otomatis tersaji dalam satu sistem di dalam program. Hal tersebut membuat data yang disajikan tidak dapat digunakan secara efektif oleh pengambil keputusan.

Secara umum semua responden sudah mengunakan aplikasi sistem informasi akuntansi (SIA) di perusahaannya. Namun hanya KWTT dan TTT saja yang sudah menggunakan program akuntansi yang khusus digunakan untuk mengolah data keuangan, sedangkan SRTT dan MTT masih menggunakan program pengolah data manual yaitu Microsoft Excel.

Dari sisi pencatatan akuntansi yang dilakukan, semua responden dari agen tour dan travel yang diteliti sudah melakukan pencatatan transaksi secara lengkap. Pencatatan yang dilakukan yaitu berupa pencatatan atas transaksi penjualan baik tiket maupun jasa lain kepada konsumen, transaksi pembelian atau pembayaran yang dilakukan kepada supplier atau maskapai, utang kepada supplier atau maskapai, piutang kepada supplier atau maskapai maupun kepada konsumen bagi agen tour dan travel yang menyediakan fasilitas DP dan pembayaran tempo, serta biaya-biaya operasional perusahaan yang dikeluarkan. 
Semua pencatatan tersebut sudah dilakukan secara rutin oleh semua agen tour dan travel setiap hari.

Dari sisi laporan keuangan yang dibuat, semua responden dari agen tour dan travel yang diteliti juga sudah membuat semua laporan keuangan dengan lengkap sesuai dengan dasar akuntansi setidaknya berdasarkan Standar Akuntansi Keuangan untuk entitas mikro, kecil, dan menengah tahun 2016 yang hanya berupa Laporan Laba Rugi, Laporan Posisi Keuangan, dan Laporan Arus Kas. Semua agen tour dan travel mengatakan bahwa semua laporan keuangan tersebut sudah secara rutin mereka buat setiap tahunnya.

\section{Implemetasi Strategi dalam menghadapi persaingan}

Dari hasil wawancara diketahui bahwa berdasarkan jenis-jenis strategi menurut Govindarajan dan Anthony (2007), strategi yang diterapkan oleh TTT adalah strategi pertahankan, dimana strategi mereka adalah fokus mempertahankan pangsa pasar yang telah mereka kuasai dengan cara meningkatkan kualitas pelayanan mereka kepada konsumen. Mereka berusaha mempertahankan konsumen yang sudah lama menjadi pelanggan dengan meningkatkan kualitas pelayanan agar konsumen tersebut tidak akan pindah dari TTT. Kemudian strategi yang diterapkan oleh MTT adalah strategi bangun, dimana strategi mereka adalah fokus menambah pangsa pasar dengan meningkatkan kerjasama dengan menjadikan sub-agen dan agen-agen sebagai mitra bisnis mereka. Selain itu, mereka juga fokus mengembangkan website dan media sosial sebagai sarana transaksi secara virtual atau online. Sedangkan strategi yang diterapkan oleh KWTT dan SRTT adalah strategi bangun dan diferensiasi, dimana strategi mereka adalah fokus menambah pangsa pasar dengan meningkatkan promosi dan melakukan kerjasama dengan intansiinstansi, serta membuat perbedaan dengan kompetitor lain melalui penyediaan dan pemberian fasilitas DP dan pembayaran tempo kepada instansi-instansi yang menjadi konsumen mereka.

Tabel 2

\section{Hasil Analisis Data}

\begin{tabular}{|c|c|c|c|c|c|c|}
\hline$\frac{110}{10}$ & Iama & II & SIII & SIA & Strattegl & \\
\hline 1 & KVWT & $\checkmark$ & & $\checkmark$ & $\gamma$ & $\sqrt{d}=3$ \\
\hline 2 & MITT & & & $\gamma$ & & $\sqrt{ }=$ \\
\hline 3 & SRTIT & $\gamma$ & & $\gamma$ & . & $\sqrt{ }=2$ \\
\hline 4 & TTI & - & . & $\gamma$ & - & $\begin{array}{l}\sqrt{ }=1 \\
(b)=3\end{array}$ \\
\hline & & $\begin{array}{l}r=2 \\
(-)=2\end{array}$ & $\begin{array}{l}V=0 \\
(v)=4\end{array}$ & $\begin{array}{l}V=4 \\
(-)=0\end{array}$ & $\begin{array}{l}r=1 \\
(t)=4\end{array}$ & \\
\hline
\end{tabular}

Sumber. Data. Pimer didaldi, 2018

Keterangan:

$\checkmark=$ Agen Travel sudah dapat memaksimalkan penerapan sistem informasi dan strategi

$(-)=$ Agen Travel belum maksimal dalam penerapan sistem informasi dan strategi

\section{Simpulan dan Saran}

\section{Simpulan}

Berdasarkan hasil analisis data, kesimpulan yang dapat diambil adalah:

1. Teknologi Informasi (TI) sudah digunakan secara maksimal oleh industri travel di Kota Yogyakarta karena sudah semua agen tour dan travel menggunakan TI dalam melakukan proses bisnis.

2. Sistem Informasi Manajemen (SIM) belum diterapkan secara maksimal oleh industri travel di Kota Yogyakarta karena mereka belum ada yang menggunakan Sistem Informasi yang terintegrasi dalam penerapannya.

3. Sistem Informasi Akuntansi (SIA) sudah diterapkan secara maksimal oleh 
industri travel di Kota Yogyakarta karena sudah semua agen tour dan travel memenuhi ke-enam komponen SIA menurut Romney dan Steinbart (2015) dalam penerapannya.

4. Strategi perusahaan sudah diterapkan dengan cukup maksimal oleh industri travel di Kota Yogyakarta karena meskipun sudah berdampak pada penjualan yang semakin meningkat, namun belum mampu mencapai target profit yang telah ditentukan.

\section{Daftar Pustaka}

Adron, M. A. F., 2016, Analisis Penerapan Sistem Akuntansi dan Laporan Keuangan serta Pengetahuan tentang SAK ETAP pada UMKM di Kabupaten Kulon Progo Yogyakarta.

Anjastantri, W., dan Dewantara, R. Y., 2017, Mempertahankan Eksistensi Tradisional Travel Agency dalam Menghadapi Ancaman Online Travel Agency, 50(6), 151-156.

Beralih ke Online Bisnis Agen Travel Mulai Redup, 2017, https://finance.detik.com/beritaekonomi-bisnis/3599286/beralih-keonline-bisnis-agen-travel-mulairedup, Diakses 16 November 2017.

Boyatzis, R., 1980,Transforming Qualitative Information: thematic analysis and code development, CA: SAGE Publication Inc.

Ceisari, B. B., 2017, Adopsi Sistem Informasi pada Industri Kreatif di Yogyakarta.

Gaol, C. J. L., 2008,Sistem Informasi Manajemen Pemahaman dan Aplikasi,

Grasindo,Diaksesdarihttps://books.go ogle.co.id/books?hl=id\&lr=\&id=VFF QD2eHGYYC\&oi=fnd\&pg=PR14\&d $\mathrm{q}=$ sistem+informasi+manajemen\&ots $=\mathrm{Ut3} \_\mathrm{J} 3 \mathrm{~J} 77 \mathrm{~V} \&$ sig $=1 \mathrm{ZohEUSiGxbP6}$ $0 \mathrm{~J} 1 \mathrm{u} 4$ reOc5BN1w\&redir_esc $=\mathrm{y} \# \mathrm{v}=\mathrm{o}$ nepage $\& \mathrm{q}=$ sistem informasi manajemen $\& \mathrm{f}=$ false.

Govindarajan, V., dan Anthony, R. N., 2007,Sistem Pengendalian Manajemen (12th ed.), McGraw-Hill.

IAI, 2016,Standar Akuntansi Keuangan: Entitas Mikro, Kecil, dan Menengah, efektif per 1 Januari 2018, IAI Press Inc.

Khumaedy, M. A., 2017, Tahun 2017 Kita Genjot Sektor Pariwisata, http://setkab.go.id/tahun-2017-kitagenjot-sektor-pariwisata/,Diakses 16 November 2017.

Kristianto, Y. B., Asni, M., Mutijo, Waluyo, dan Oktavia, G., 2016, Statistik Daerah Daerah Istimewa Yogyakarta 2016, 1-82.

Laudon, K. C., dan Laudon, J. P., 2014,Management Information Systems: Managing Digital Firm (13th ed.), Pearson Education.

Moleong, L. J., 2014,Metodologi Penelitian Kualitatif, Bandung: Remaja Rosdakarya.

Musmini, L. S., 2013, Sistem Informasi Akuntansi Untuk Menunjang Pemberdayaan Pengelolaan Usaha Kecil,Vokasi Jurnal Riset Akuntansi, 2(1), 62-81.

Romney, M. B., dan Steinbart, P. J., 2015,Accounting Information System (13th ed.), Perason Education.

Saunders, M., Lewis, P., dan Thornhill, A., 2012,Research Methods for Business Students (Sixth), Pearson Education Limited.

Sekaran, U., dan Bougie, R., 2017,Metode Penelitian untuk Bisnis (6th ed.), Jakarta: Salemba Empat.

Tren Pemesanan Tiket Kereta Api Online Meningkat Tiap Tahun, 2016, http://kereta-api.info/tren-pemesanantiket-kereta-api-online-meningkattiap-tahun-6432.htm, Diakses 16 November 2017.

Urumsah, D., 2014,Perencanaan Strategis Sistem Informasi (1st ed.), Yogyakarta: Data Algonia.

Wahid, F., dan Iswari, L., 2007, Adopsi 
Jurnal Akuntansi Maranathan Volume 10 Nomor 2, November 2018 : 139-148

Teknologi Informasi oleh

UKM,Seminar, 2007(Snati),75-

79,Diakses dari

http://journal.uii.ac.id/index.php/Snati

/article/viewFile/1732/1512. 